\title{
SYNTHESIS AND EVALUATION OF THE ANTIMICROBIAL AND ANTIBIOFILM ACTIVITY OF NOVEL DIBENZOTHIEPINES
}

\author{
CAMELIA ELENA STECOZA ${ }^{1}$, CONSTANTIN DRĂGHICI ${ }^{2}$, MIRON TEODOR CĂPROIU ${ }^{2}$, \\ GRAȚIELA GRĂDIȘTEANU PÎRCĂLĂBIORU ${ }^{3 *}$, LUMINIȚA MĂRUȚESCU ${ }^{3}$ \\ 1 "Carol Davila” University of Medicine and Pharmacy, Faculty of Pharmacy, Department of Pharmaceutical Chemistry, 6 \\ Traian Vuia Street, 020956, Bucharest, Romania \\ 2 “Costin D. Neniţescu” Centre of Organic Chemistry Romanian Academy, 202 B Splaiul Independenţei, 060023, Bucharest, \\ Romania \\ ${ }^{3}$ Research Institute of University of Bucharest, 60101, Bucharest, Romania
}

*corresponding author: gratiela87@gmail.com

Manuscript received: May 2020

\begin{abstract}
Considering the anti-infective potential of compounds containing the dibenzothiepine scaffold, we set out to obtain new compounds bearing this structure. The synthesized compounds were characterized by spectral studies and elemental analysis and screened for their microbiostatic/microbicidal and antibiofilm properties against reference and clinical microbial strains. The new compounds exhibited a broad spectrum of antimicrobial activity, which was more intensive for the S-oxidized compounds. Some of the compounds also inhibited the ability of the investigated strains to form biofilms on the inert substratum.
\end{abstract}

\section{Rezumat}

Având în vedere potențialul antiinfecțios al compușilor cu structură dibenzotiepinică, în prezenta lucrare ne-am propus să obținem noi derivați care au la bază acest nucleu. Compuşii sintetizaţi au fost caracterizaţi prin analize spectrale și analiză elementală și au fost determinate proprietățile antimicrobiene și antibiofilm față de tulpini microbiene de referință și clinice. Noii compuși au prezentat activitate antimicrobiană cu spectru larg, superioară pentru compușii S-oxidați. Unii dintre compuşi au inhibat, de asemenea, capacitatea tulpinilor microbiene de a forma biofilm pe substratul inert.

Keywords: dibenzothiepines, sulfones, antimicrobial, antibiofilm

\section{Introduction}

The development and approval of new anti-infective agents efficient against multidrug-resistant, extendeddrug and pan-drug resistant pathogens has not kept up with the evolution of drug resistance in these microorganisms. World Health Organization reports show that every year, antimicrobial resistant infections caused 700,000 deaths, with 10 million deaths predicted by 2050 if this trend continues. The prognosis is worsened by the formation of bacterial biofilms, represented by microbial communities adhered to a surface or an interface, embedded in a self-secreted polymeric matrix, which exhibit a highly resistant phenotype to different antimicrobial agents, host defence mechanisms and other limiting conditions. With biofilms being involved in up to $80 \%$ of the total number of infections, often with chronic evolution, the need for antibiofilm compounds has become obvious. Antibiofilm compounds can act either on the cellular component of microbial biofilms or by disrupting the biofilm matrix, rendering the free cells susceptible to antibiotics and/or to the immune system effectors.
It is well known that development of novel compounds is time-consuming and requires immense resources. For the past few decades the number of newly approved antibiotics has decreased significantly. For these threats and challenges to be countered, there is an urgent need to identify alternative strategies to obtain new active compounds to control infectious diseases $[1,2,4,6$, 13, 19-21].

An alternative approach for drug discovery is the screening of large chemical libraries using highthroughput technique. This technique has gained widespread popularity over the last two decades and has become a standard method for drug discovery in the pharmaceutical industry $[9,18]$.

High-throughput screening led to the identification of active anti-infective agents with dibenzothiepine scaffold. Dibenzothiepine compounds proved to exhibit various activities, such as antibacterial, antifungal, antiprotozoal [5, 12, 14], some compounds having efficacy against biofilms [15].

In our previous researches we highlighted the antibacterial, antifungal and antibiofilm activity of some new compounds with dibenzothiepine scaffold [7, 17]. Based on all above considerations and as an extension 
of our research in development of new compounds with anti-infective properties, we have designed and synthesized new dibenzothiepine derivatives which were evaluated for their antibacterial and anti-biofilm activities.

\section{Materials and Methods}

\section{Chemistry}

All starting materials, reagents and solvents were purchased from commercial suppliers (Merck, SigmaAldrich or Fluka) and used without further purification unless otherwise specified. All melting points were measured in open capillary tubes on an Electrothermal 9100 apparatus and are uncorrected. The elemental analyses were performed on a Perkin-Elmer 2400 Series II CHNS/O Elemental Analyzer (Shelton, CT, USA). The NMR spectra were recorded on a Gemini $300 \mathrm{BB}$ instrument (Varian, Palo Alto, CA, USA) at room temperature, operating at $300 \mathrm{MHz}$ for ${ }^{1} \mathrm{H}$ and $75 \mathrm{MHz}$ for ${ }^{13} \mathrm{C}$, using deuterochloroform $\left(\mathrm{CDCl}_{3}\right)$ as solvent. The chemical shifts were recorded as $\delta$ values in parts per million (ppm) relative to tetramethylsilane (TMS), used as internal standard. The coupling constants (J) values are reported in Hertz and the splitting patterns are abbreviated as following: s (singlet), d (doublet), $\mathrm{t}$ (triplet), q (quartet), $\mathrm{m}$ (multiplet), b (broad). The ${ }^{13} \mathrm{C}$-NMR data are reported in the following order: chemical shifts (ppm), the signal/atom attribution, the coupling constant $(\mathrm{J})$ in some cases; Cq-quaternary carbon.

The IR spectra were recorded on a Bruker Vertex 70 spectrometer, with horizontal device for attenuated reflectance and diamond crystal, on a spectral window ranging from 4000 to $400 \mathrm{~cm}^{-1}$. The spectra were recorded without any sample preparation and were processed with OPUS 5.5 program (Bruker). The IR bands were given as: w (weak), $\mathrm{m}$ (medium), s (strong), vs (very strong).

Synthesis

The new compounds were synthesized by the general method, outlined in Figure 1, starting from phtalide 1 and potassium thiophenolate $2(\mathrm{X}=-\mathrm{H})$ or potassium p-thiocresolate $2\left(\mathrm{X}=-\mathrm{CH}_{3}\right)$.

In the first stage we obtained acids $\mathbf{3}$, which were transformed into the corresponding ketones $\mathbf{4}$ in the presence of polyphosphoric acid and then converted to the corresponding oximes 5 by treatment with hydroxylamine hydrochloride in the presence of pyridine. Dibenzo[b,e]thiepines $\mathbf{T H}$ and $\mathbf{T M}$ were prepared by acylation of the corresponding oximes $\mathbf{5}$ with various aromatic acid chlorides, in dry benzene/toluene and in the presence of anhydrous pyridine as a proton acceptor. Sulfones SH and SM were prepared by the oxidation of dibenzo[b,e]thiepines TH respectively $\mathbf{T M}$, with $30 \%$ aqueous hydrogen peroxide in glacial acetic acid, at boiling temperature.<smiles>O=C1OCc2ccccc21</smiles><smiles>[X]c1ccc(S)cc1</smiles><smiles>[X]c1ccc2c(c1)C(=O)c1ccc(C(C)C)cc1CS2</smiles><smiles>[R]C(=O)O/N=C1/c2ccccc2CSc2ccc([X])cc21</smiles>

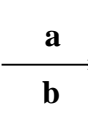<smiles>[X]c1ccc(SCc2ccccc2C(=O)O)cc1</smiles><smiles>[CaH]</smiles><smiles>[X]c1ccc2c(c1)C(=NO)c1ccccc1CS2</smiles><smiles>[R]C(=O)O/N=C1/c2ccccc2CS(=O)(=O)c2ccc([X])cc21</smiles>

$\mathrm{X}=\mathrm{H}, \mathrm{CH}_{3}$ $\mathrm{R}=$ substituted aryl

Figure 1.

The synthetic pathway of the dibenzo[b,e]thiepines TH and TM and dibenzo[b,e]thiepine-5,5-dioxides, SH and SM Reagents and conditions: (a) xylene, reflux; 10\% sodium hydroxide; (b) hydrochloric acid $1 \mathrm{M}$; (c) polyphosphoric acid 140 $150^{\circ} \mathrm{C}, 3 \mathrm{~h}$; (d) hydroxylamine hydrochloride, pyridine, reflux, $24 \mathrm{~h}$; (e) aromatic acid chlorides, benzene, pyridine, reflux, $2 \mathrm{~h}$;

(f) $30 \%$ aqueous hydrogen peroxide, glacial acetic acid, reflux, $3 \mathrm{~h}$ 
Acids $\mathbf{3}$, ketones $\mathbf{4}$ and oximes $\mathbf{5}$, were prepared in good yields $(85-91 \%)$ according to the previously described procedures [7, 16, 17].

General procedure for the synthesis of the new derivatives of $\mathbf{T H}$ series

To a solution of $10 \mathrm{mmol}$ 11-hydroximino-6,11-dihydrodibenzo[b,e]thiepine in anhydrous toluene was added dropwise a solution of $11 \mathrm{mmol}$ appropriated chloride acid in anhydrous toluene and $0.8 \mathrm{~mL}(10$ mmol) dry pyridine. The reaction mixture was refluxed for three hours, cooled, the precipitate was filtered off and the solvent removed under reduced pressure. The resulting crude product was recrystallized from isopropanol.

General procedure for the synthesis of the new derivatives of $\mathbf{S H}$ series

To a solution of $10 \mathrm{mmol}$ compound $\mathrm{TH}$, in glacial acetic acid, $2 \mathrm{~mL}$ of $30 \%$ aqueous hydrogen peroxide were added dropwise. The mixture was heated for three hours and then left overnight at room temperature. The reaction mixture was diluted with water and extracted with chloroform. The combined organic layer was dried over calcium chloride and after filtration, the solvent removed under reduced pressure. The resulting crude product was recrystallized from ethanol.

Synthesis of [(5,5-dioxo-6,11-dihydrodibenzo[b,e]thiepin-2-methyl-11-ylidene)amino] 3,4,5-trimethoxybenzoate (SM22)

To a solution of $10 \mathrm{mmol}$ 2-methyl-11-hydroximino6,11-dihydrodibenzo[b,e]thiepine $5\left(\mathrm{X}=-\mathrm{CH}_{3}\right)$ in anhydrous benzene was added dropwise a solution of $11 \mathrm{mmol}$ 3,4,5-trimethoxybenzoyl chloride in anhydrous benzene and $0.8 \mathrm{~mL}(10 \mathrm{mmol})$ dry pyridine. The reaction mixture was refluxed for three hours, cooled, the precipitate was filtered off and the solvent removed under reduced pressure. The resulting crude product was recrystallized from ethanol, and afterward oxidized using a solution of $30 \%$ aqueous hydrogen peroxide according to the protocol described above. The resulting crude product was recrystallized from glacial acetic acid.

Antimicrobial activity evaluation against planktonic and biofilm embedded cells

The antimicrobial properties of the new compounds were investigated using the broth micro-dilution assay. The compounds were solubilized in dimethyl sulfoxide (DMSO) and further diluted two-fold in 96 well plates containing Muller Hinton Broth (MHB). Microbial suspensions of Gram-negative bacteria (Escherichia coli ATCC 8739, Pseudomonas aeruginosa ATCC 27853) and Gram-positive bacteria (Enterococcus faecalis ATCC 29212, Staphylococcus aureus ATCC 6538) and Candida parapsilopsis ATCC 22019 with a density of $10^{6} \mathrm{CFU} / \mathrm{mL}$ were also prepared from $24 \mathrm{~h}$ solid cultures. We have also used clinical isolates consisting of methicillin resistant S. aureus (MRSA), uropathogenic E. coli (UPEC), Acinetobacter baumanii and $P$. aeruginosa. The microbial suspensions were then inoculated on each microtiter well containing the two-fold dilutions of the tested compounds. A sterility control was added with $100 \mu \mathrm{L}$ of MHB. The experiments were done in triplicate. The wells were incubated for $18-24 \mathrm{~h}$ in aerobic conditions, at $37^{\circ} \mathrm{C}$. After incubation, the minimum inhibitory concentration (MIC) value was determined spectrophotometrically at $620 \mathrm{~nm}$.

To investigate the influence of the tested compounds on the ability of the tested microbial strains to colonize the inert substratum, a microtiter plate method was performed. The microplates used for the MIC assay were emptied and further washed three times with phosphate buffered saline. The biofilm formed on the plastic wells wall was fixed for $5 \mathrm{~min}$ with cold methanol, coloured by violet crystal solution (15 min) and finally re-suspended in 33\% acetic acid solution. Microbial cell density measurement was done by reading the optical density of the coloured solution at $490 \mathrm{~nm}$. The minimal biofilm eradication concentration (MBEC) values were considered as the lowest concentration of the tested compound that inhibited the development of biofilm on the plate wells [11].

\section{Results and Discussion}

\section{Chemistry}

Following the aforementioned synthesis procedure, we obtained new O-acyl-oximino-dibenzo[b,e]thiepines (TH) and sulfones (SH), solid, crystalline, white compounds that were characterized by NMR and IR spectra. The compounds purity was certified by elemental analyses, the results being within \pm 0.4 of the theoretical values.

The chemical structures of the new compounds, dibenzothiepine derivatives of the $\mathrm{TH}$ and $\mathrm{SH}$ series are depicted in Table I. The structure of the already reported compound SM22 is included in the table.

The melting point (m.p.), the reaction yield, spectral data and elemental analysis for O-acyl-oximino-dibenzo[b,e]thiepins $\mathbf{T H}$ and their corresponding 5,5dioxides SH are presented here. For compound SM22, whose synthesis and characterization have already been reported, the main chemical data are presented. [(6,11-dihydrodibenzo[b,e]thiepin-11-ylidene)amino] 2,3,4-trimethoxybenzoate (TH47)

m.p.: $119-120^{\circ} \mathrm{C}$; white solid; yield $68 \%$.

${ }^{1} \mathrm{H}-\mathrm{NMR}\left(\mathrm{CDCl}_{3}, \delta \mathrm{ppm}, J \mathrm{~Hz}\right): 7.85(\mathrm{dd}, 1.4 ; 7.7 ; 1 \mathrm{H}$, H-1); 7.12 - 7.42 (m, 8H, H-arom); 6.60 (d, 8.8, 1H, $\mathrm{H}-17$ ); 4.70 (bs, $2 \mathrm{H}, \mathrm{H}-6$ ); 3.87 (s, $3 \mathrm{H}, \mathrm{OCH}_{3}{ }^{19}$ ); 3.82 (s, $\left.3 \mathrm{H}, \mathrm{OCH}_{3}{ }^{21}\right) ; 3.65\left(\mathrm{~s}, 3 \mathrm{H}, \mathrm{OCH}_{3}{ }^{20}\right)$.

${ }^{13} \mathbf{C}-\mathbf{R M N}\left(\mathrm{CDCl}_{3}, \delta \mathrm{ppm}\right): 166.50$ (C-12); 162.83 (C-11); $157.63(\mathrm{Cq}) ; 155.11(\mathrm{Cq}) ; 143.02$ (Cq); 136.87 (Cq); $135.02(\mathrm{Cq}) ; 133.88(\mathrm{Cq}) ; 131.84(\mathrm{CH}) ; 130.54$ $(\mathrm{CH}) ; 130.31(\mathrm{CH}) ; 129.18(\mathrm{Cq}) ; 128.01(\mathrm{CH}) ; 127.40$ $(\mathrm{CH}) ; 127.34(\mathrm{CH}) ; 127.03(\mathrm{CH}) ; 126.46(\mathrm{CH}) ; 125.09$ (CH); 116.19 (Cq-13); 106.99 (CH-18); $61.60\left(\mathrm{OCH}_{3}{ }^{19}\right)$; $61.06\left(\mathrm{OCH}_{3}{ }^{21}\right) ; 56.17\left(\mathrm{OCH}_{3}{ }^{20}\right) ; 33.40(\mathrm{C}-6)$. 
The spectra results show that only one stereoisomer is present.

FT-IR (ATR in solid, $v \mathrm{~cm}^{-1}$ ): 3056w; 2966w; 2932w; 2834w; 1752vs; 1594m; 1495w; 1461m; 1416m; 1255vs; 1209w; 1171w; 1127m; 1091s; 1019s; 986w; 932w; 895m; 777w; 731w; 698w; 587w.
Elemental analysis: Calcd. for $\mathrm{C}_{24} \mathrm{H}_{21} \mathrm{NO}_{5} \mathrm{~S}$ (435.50 g/mol): C, 66.19; H, 4.86; N, 3.22; S, 7.36. Found: C, 66.31; H, 5.10; N, 3.03; S, 7.16.

Table I

The chemical structures of the dibenzothiepine compounds from the three series: TH, SH and SM

\begin{tabular}{|c|c|c|c|c|}
\hline Series & Experimental compound code & $\mathbf{X}$ & $\mathbf{Y}$ & $\mathbf{R}$ \\
\hline \multirow{3}{*}{$\mathrm{TH}$} & TH47 & $\mathrm{H}$ & $\mathrm{S}$ & $2,3,4-\left(\mathrm{H}_{3} \mathrm{CO}\right)_{3}-\mathrm{C}_{6} \mathrm{H}_{2}$ \\
\hline & TH48 & $\mathrm{H}$ & $\mathrm{S}$ & $2,3,4-(\mathrm{F})_{3}-\mathrm{C}_{6} \mathrm{H}_{2}$ \\
\hline & TH49 & $\mathrm{H}$ & $\mathrm{S}$ & $3-\mathrm{F}_{3} \mathrm{C}-\mathrm{C}_{6} \mathrm{H}_{4}$ \\
\hline \multirow{3}{*}{ SH } & SH47 & $\mathrm{H}$ & $\mathrm{SO}_{2}$ & $2,3,4-\left(\mathrm{H}_{3} \mathrm{CO}\right)_{3}-\mathrm{C}_{6} \mathrm{H}_{2}$ \\
\hline & SH48 & $\mathrm{H}$ & $\mathrm{SO}_{2}$ & $2,3,4-(\mathrm{F})_{3}-\mathrm{C}_{6} \mathrm{H}_{2}$ \\
\hline & SH49 & $\mathrm{H}$ & $\mathrm{SO}_{2}$ & $3-\mathrm{F}_{3} \mathrm{C}-\mathrm{C}_{6} \mathrm{H}_{4}$ \\
\hline SM & SM22 & $\mathrm{CH}_{3}$ & $\mathrm{SO}_{2}$ & $3,4,5-\left(\mathrm{H}_{3} \mathrm{CO}\right)_{3}-\mathrm{C}_{6} \mathrm{H}_{2}$ \\
\hline
\end{tabular}

[(6,11-dihydrodibenzo[b,e]thiepin-11-ylidene)amino] 2,3,4-trifluorobenzoate ( $\mathbf{T H 4 8}$ )

m.p.: $168-170^{\circ} \mathrm{C}$; white solid; yield $69 \%$.

${ }^{\mathbf{1}} \mathbf{H}-\mathbf{N M R}\left(\mathrm{CDCl}_{3}, \delta \mathrm{ppm}, J \mathrm{~Hz}\right): 7.81(\mathrm{dd}, 7.7,1.6,1 \mathrm{H}$, $\mathrm{H}-1)$; 7.58 (m, 1H, H-18); 7.20 - 7.50 (m, 5H, H-arom); 7.18 (td, 1.7, 7.7, 1H, H-2); 7.14 (dd, 1.4, 7.9, 1H, H-4); 6.98 (m, 1H, H-17); 4.64 (bs, 1H, H-6); 3.55 (bs, 1H, H-6').

${ }^{13} \mathbf{C}-\mathbf{R M N}\left(\mathrm{CDCl}_{3}, \delta\right.$ ppm, $\left.J \mathrm{~Hz}\right)$ : 168.21 (C-12); 161.44 (C-11); 137.25 (Cq); $134.80(\mathrm{Cq}) ; 133.24(\mathrm{Cq}) ; 131.78$ $(\mathrm{CH}) ; 130.84(\mathrm{CH}) ; 130.62(\mathrm{CH}) ; 128.62(\mathrm{Cq}) ; 128.20$ $(\mathrm{CH}) ; 127.42(\mathrm{CH}) ; 127.30(\mathrm{CH}) ; 126.51(\mathrm{CH}) ; 126.40$ $(\mathrm{CH}) ; 125.14(\mathrm{CH}) ; 112.50$ (dd, 17.6, 3.4, CH-17); 33.42 (C-6).

The spectra results show that only one stereoisomer is present. The presence of the three fluorine atoms in the aromatic ring makes impossible the description of corresponding ${ }^{13} \mathrm{C}$-NMR signals. This is due to the very close chemical shifts ( $160 \mathrm{ppm})$ and also due to the long range couplings with the other fluorine atoms.

FT-IR (ATR in solid, $v \mathrm{~cm}^{-1}$ ): 3054w; 2910w; 1736vs; $1621 \mathrm{~m} ; 1506 \mathrm{~m} ; 1472 \mathrm{~s} ; 1424 \mathrm{w} ; 1314 \mathrm{~m} ; 1282 \mathrm{~s} ; 1191 \mathrm{vs}$; 1102s; 1072w; 1044 m; 982w; 933w; 858m; 827w; 771m; 722w; 698w; 638w; 592w; 468w.

Elemental analysis: Calcd. for $\mathrm{C}_{21} \mathrm{H}_{12} \mathrm{~F}_{3} \mathrm{NO}_{2} \mathrm{~S}$ (399.39 g/mol): C, 63.15; H, 3.03; N, 3.51; S, 8.03. Found: C, 63.36; H, 3.23; N, 3.45; S, 8.14.

[(6,11-dihydrodibenzo[b,e]thiepin-11-ylidene)amino] 3-(trifluoromethyl)benzoate (TH49)

m.p.: $132-134^{\circ} \mathrm{C}$; white solid; yield $72 \%$.

${ }^{1} \mathbf{H}-\mathbf{N M R}\left(\mathrm{CDCl}_{3}, \delta \mathrm{ppm}, J \mathrm{~Hz}\right): 7.92(\mathrm{bd}, 7.7,1 \mathrm{H}$, H-18); 7.86 (bs, 1H, H-14); 7.77 (dd, 1.5, 7.7, 1H, H-1); 7.69 (bd, 7.7, 1H, H-16); 7.44 (t, 7.7, 1H, H-17);
7.05 - 7.45 (m, 7H, H-arom); 4.55 (bs, 1H, H-6); 3.52 (bs, 1H, H-6').

${ }^{13} \mathbf{C}-\mathbf{R M N}\left(\mathrm{CDCl}_{3}, \delta\right.$ ppm, $\left.J \mathrm{~Hz}\right): 167.78$ (C-12); 162.15 (C-11); $137.20(\mathrm{Cq}) ; 135.19(\mathrm{Cq}) ; 133.08$ (Cq); 132.94 $(\mathrm{CH}) ; 131.79(\mathrm{CH}) ; 131.40(\mathrm{Cq}) ; 131.2$ (q, 32.5, C-15); $130.82(\mathrm{CH}) ; 130.61(\mathrm{CH}) ; 129.93(\mathrm{CH}) ; 129.47(\mathrm{Cq})$; $129.32(\mathrm{CH}) ; 128.47(\mathrm{Cq}) ; 127.26(\mathrm{CH}) ; 127.14(\mathrm{CH})$; $126.71(\mathrm{CH}) ; 126.60(\mathrm{CH}) ; 125.16(\mathrm{CH}) ; 123.49(\mathrm{q}$, 267.8, $\left.\mathrm{CF}_{3}\right) 33.50$ (C-6).

The spectra results show that only one stereoisomer is present.

FT-IR (ATR in solid, $v \mathrm{~cm}^{-1}$ ): 3097w; 3069w; 2963w; 2331w; 2116w; 1985w; 1930w; 1754vs; 1592m; 1474w; $1419 \mathrm{w} ; 1327 \mathrm{~s} ; 1259 \mathrm{w} ; 1223 \mathrm{vs} ; 1173 \mathrm{~m} ; 1121 \mathrm{~s} ; 1055 \mathrm{vs}$; 979m; 923w; 882m; 817w; 765w; 736m; 693m; 639w; 594w.

Elemental analysis: Calcd. for $\mathrm{C}_{22} \mathrm{H}_{14} \mathrm{~F}_{3} \mathrm{NO}_{2} \mathrm{~S}$ (413.42 g/mol): C, 63.92; H, 3.41; N, 3.39; S, 7.76. Found: C, 64.04; H, 3.49; N, 3.48; S, 7.87.

[(5,5-dioxo-6,11-dihydrodibenzo[b,e]thiepin-11ylidene)amino] 2,3,4-trimethoxybenzoate (SH47) m.p.: $200-202^{\circ} \mathrm{C}$; white solid; yield $82 \%$.

${ }^{1} \mathbf{H}-\mathbf{R M N}\left(\mathrm{CDCl}_{3}, \delta\right.$ ppm, J Hz): 8.04 (dd, 7.2, 1.6, $1 \mathrm{H}, \mathrm{H}-4) ; 7.91$ (dd, 7.7, 1.6, 1H, H-1); 7.69 (td, 7.2, 1.6, 1H, H-3); 7.64 (td, 7.7, 1.6, 1H, H-2); 7.35 - 7.55 (m, 4H, H-arom); 7.32 (d, 8.8, 1H, H-18); 6.61 (d, 8.8, 1H, H-17); 5.05 (bs, 1H, H-6); 4.20 (bs, 1H, H-6'); $3.88\left(\mathrm{~s}, 3 \mathrm{H}, \mathrm{OCH}_{3}\right) ; 3.82\left(\mathrm{~s}, 3 \mathrm{H}, \mathrm{OCH}_{3}\right) ; 3.67(\mathrm{~s}, 3 \mathrm{H}$, $\left.\mathrm{OCH}_{3}\right)$.

${ }^{13} \mathbf{C}-\mathbf{R M N}\left(\mathrm{CDCl}_{3}, \delta, \mathrm{ppm}\right): 163.55(\mathrm{C}-12) ; 162.32$ (C-11); 158.09 (Cq); $155.30(\mathrm{Cq}) ; 143.11(\mathrm{Cq}) ; 141.85$ $(\mathrm{Cq}) ; 135.37(\mathrm{Cq}) ; 132.85(\mathrm{CH}-2) ; 132.27(\mathrm{CH}-3)$; $131.43(\mathrm{CH}) ; 130.34(\mathrm{Cq}) ; 130.07(\mathrm{CH}) ; 129.21(\mathrm{CH})$; $128.15(\mathrm{CH}) ; 127.14$ (CH-18); 126.20 (CH-4); 124.37 
FARMACIA, 2020, Vol. 68, 6

(Cq); 115.39 (Cq-13); 107.12 (C-17); $61.65\left(\mathrm{OCH}_{3}\right)$; $61.09\left(\mathrm{OCH}_{3}\right) ; 58.58(\mathrm{C}-6) ; 56.24\left(\mathrm{OCH}_{3}\right)$.

The spectra results show that only one stereoisomer is present.

FT-IR (ATR in solid, $v \mathrm{~cm}^{-1}$ ): 3065w; 2998w; 2938w; 2834w; 2113w; 1994w; 1908w; 1756w; 1725vs; 1585m; $1488 \mathrm{w} ; 1459 \mathrm{~m} ; 1408 \mathrm{~m} ; 1295 \mathrm{~s} ; 1259 \mathrm{vs} ; 1209 \mathrm{~m} ; 1156 \mathrm{w}$; $1106 \mathrm{vs} ; 1016 \mathrm{~m}$; 979w; 929w; 888w; 819w; 785m; 740w; 684w; 636w; 604w; 523m.

Elemental analysis: Calcd. for $\mathrm{C}_{24} \mathrm{H}_{21} \mathrm{NO}_{7} \mathrm{~S}(467.50$ g/mol): C, 61.66; H, 4.53; N, 3.00; S, 6.86. Found: C, $61.48 ; \mathrm{H}, 4.61 ; \mathrm{N}, 3.14 ; \mathrm{S}, 6.76$.

[(5,5-dioxo-6,11-dihydrodibenzo[b,e]thiepin-11ylidene)amino] 2,3,4-trifluorobenzoate (SH48). m.p.: $213-215^{\circ} \mathrm{C}$; white solid; yield $81 \%$.

${ }^{1} \mathrm{H}$-NMR $\left(\mathrm{CDCl}_{3}, \delta \mathrm{ppm}, J \mathrm{~Hz}\right): 8.05(\mathrm{dd}, 7.4,1.7$, 1H, H-4); 7.87 (dd, 7.4, 1.6, 1H, H-1); 7.40 - 7.75 (m, 7H, H-arom); 7.02 (m, 1H, H-17); 5.06 (bs, 1H, H-6); 4.38 (bs, 1H, H-6').

${ }^{13} \mathbf{C}-\mathbf{R M N}\left(\mathrm{CDCl}_{3}, \delta \mathrm{ppm}\right): 165.26(\mathrm{C}-12) ; 141.92$ (C-11); $134.62(\mathrm{Cq}) ; 132.87(\mathrm{CH}) ; 132.55(\mathrm{CH}) ; 131.41$ $(\mathrm{CH}) ; 131.23(\mathrm{CH}) ; 129.91(\mathrm{CH}) ; 129.71(\mathrm{Cq}) ; 129.21$ $(\mathrm{CH}) ; 128.07(\mathrm{CH}) ; 126.86(\mathrm{CH}) ; 126.34(\mathrm{CH}) ; 123.92$ (Cq); 112.75 (d, 17.3, C-17); 58.55 (C-6).

Quaternary atoms due to fluorine couplings and over several links disappear into the base line of the spectrum. The spectra results show that only one stereoisomer is present.

FT-IR (ATR in solid, $v \mathrm{~cm}^{-1}$ ): 3073w; 2965w; 2925w; 2361w; 1748vs; 1614m; 1509m; 1477s; 1423w; 1305s; 1283s; 1193s; 1159m; 1128m; 1095m; 1066w; 990w; 933m; 880w; 828w; 785m; 722w; 682w; 635w; 605w; 566w; 521m; 484w.

Elemental analysis: Calcd. for $\mathrm{C}_{21} \mathrm{H}_{12} \mathrm{~F}_{3} \mathrm{NO}_{4} \mathrm{~S}$ (431.39 g/mol): C, 58.47; H, 2.80; N, 3.25; S, 7.43. Found: C, $58.39 ; \mathrm{H}, 2.87 ; \mathrm{N}, 3.16 ; \mathrm{S}, 7.51$.

[(5,5-dioxo-6,11-dihydrodibenzo[b,e]thiepin-11ylidene)amino] 3-(trifluoromethyl)benzoate (SH49) m.p.: $187-189^{\circ} \mathrm{C}$; white solid; yield $84 \%$.

${ }^{1} \mathbf{H}$-NMR $\left(\mathrm{CDCl}_{3}, \delta \mathrm{ppm}, J \mathrm{~Hz}\right): 8.06(\mathrm{dd}, 7.7,1.7,1 \mathrm{H}$, H-4); 8.00 (bd, 7.7, 1H, H-18); 7.93 (bs, 1H, H-14); 7.91 (dd, 7.7, 1.7, 1H, H-1); 7.81 (bd, 7.7, 1H, H-16); 7.40 - 7.75 (m, H-arom); 5.08 (bs, 1H, H-6); 4.40 (bs, 1H, H-6').

${ }^{13} \mathbf{C}-\mathbf{R M N}\left(\mathrm{CDCl}_{3}, \delta\right.$ ppm, $\left.J \mathrm{~Hz}\right): 164.95$ (C-12); 161.73 (C-11); 141.96 (Cq); 134.54 (Cq); $130.04(\mathrm{CH}) ; 132.91$ $(\mathrm{CH}) ; 132.56(\mathrm{CH}) ; 131.31(\mathrm{CH}) ; 131.37(\mathrm{Cq}-15, J=$ $32.3) ; 130.34$ (q, $J=2.8, \mathrm{CH}) ; 130.00(\mathrm{CH}) ; 129.62$ $(\mathrm{Cq}) ; 129.53(\mathrm{CH}) ; 129.07(\mathrm{CH}) ; 128.86(\mathrm{Cq}) ; 127.85$ $(\mathrm{CH}) ; 127.03\left(\mathrm{q}, J=270, \mathrm{CF}_{3}\right) ; 126.64(\mathrm{q}, J=3.0$, CH-16); $126.32(\mathrm{CH}) ; 124.31$ (Cq); 58.60 (C-6).

The spectra results show that only one stereoisomer is present.

Elemental analysis: Calcd. for $\mathrm{C}_{22} \mathrm{H}_{14} \mathrm{~F}_{3} \mathrm{NO}_{4} \mathrm{~S}$ (445.42 g/mol): C, 59.32; H, 3.17; N, 3.14; S, 7.20. Found: C, $59.04 ; \mathrm{H}, 3.35 ; \mathrm{N}, 3.43 ; \mathrm{S}, 7.40$. [(5,5-dioxo-6,11-dihydrodibenzo[b,e]thiepin-2methyl-11-ylidene)amino] 3,4,5- trimethoxybenzoate (SM22)

$\mathrm{C}_{25} \mathrm{H}_{23} \mathrm{NO}_{7} \mathrm{~S}(481.53 \mathrm{~g} / \mathrm{mol})$; m.p.: $228-231^{\circ} \mathrm{C}$; white solid; yield $64 \%$.

In the ${ }^{1} \mathrm{H}-\mathrm{NMR}$ spectra of the new dibenzo[b,e]thiepines TH the dibenzothiepine scaffold is characterized by the methylene group $\mathrm{CH}_{2} \mathrm{~S}$ (H-6) which gave an $\mathrm{AB}$ coupling system, with two broad singlets at $3.52-3.55$ ppm and $4.55-4.70 \mathrm{ppm}$. The magnetically nonequivalent diastereotopic protons $\mathrm{H}-6$ and $\mathrm{H}-6$ ' form an AB system. The $S$-oxidation to the corresponding dioxides (compounds $\mathrm{SH}$ ) induces as direct effect the deshielding (approximately $1 \mathrm{ppm}$ ) of the two protons of the methylenic group, which appear in sulfones in the range $4.20-4.40 \mathrm{ppm}$ and 5.05 $5.08 \mathrm{ppm}$. At $303 \mathrm{~K}$ the signals appear broadened due to the slow exchange between the two positions (a flip between two conformers).

In the ${ }^{13} \mathrm{C}$-NMR spectra of the new dibenzo[b,e]thiepines $\mathrm{TH}$ the methylene group (C-6) is characterized by a signal at $33.40-33.50 \mathrm{ppm}$. The S-oxidation to the corresponding sulfone derivatives induces as direct effect a strongly deshielding (approximately $25 \mathrm{ppm}$ ) of the carbon of the methylenic group, which appear in sulfones $\mathrm{SH}$ in the range $58.55-58.60 \mathrm{ppm}$. The signal corresponding to the $\mathrm{C}-11$ atom appears in the range $141.92-162.83 \mathrm{ppm}$ and the signal of C-12 appears in the range $163.55-168.21 \mathrm{ppm}$. The other signals are in good agreement with the structure. Owing to the asymmetry induced by sulphur in dibenzothiepine nucleus, the compounds belong to the two series TH and SH, may have syn or anti configuration. NMR spectral data showed the presence of only one of the stereoisomers in all newly synthesized compounds, most probably the anti-isomer.

In the IR spectra the characteristic bands for the new compounds are $\left(\mathrm{cm}^{-1}\right): v \mathrm{vH}_{2} 1327-1424 ; \mathrm{vCH}_{2}$ 2834 - 2963; - $\mathrm{O}-\mathrm{C}=\mathrm{O}(v \mathrm{C}=\mathrm{O}: 1725$ - 1754; vC-O: $1156-1223) ; v \mathrm{C}=\mathrm{N}$ : $1585-1621$; aromatic rings $(v=\mathrm{C}-\mathrm{H}: 3054-3073 ; v \mathrm{C}=\mathrm{C}: 1585-1621)$; for compounds $\mathrm{SH}: v_{\mathrm{SO}_{2}}$ sym $1156-1191, v^{2} \mathrm{SO}_{2}$ asym $1305-1327$.

Bioevaluation

The antimicrobial and antibiofilm activity of the novel compounds was tested against reference strains of Staphylococcus aureus, Enterococcus faecalis, Escherichia coli, Pseudomonas aeruginosa and Candida parapsilosis as well as clinical isolates including Acinetobacter baumannii, $P$. aeruginosa, methicillin resistant $S$. aureus (MRSA) and uropathogenic E. coli (UPEC) (Figures 2 and 3).

The quantitative assay revealed the presence of antimicrobial activity for all tested compounds, with MIC values of $1.25-10 \mathrm{mg} / \mathrm{mL}$. The lowest MIC values $(1.25-2.5 \mathrm{mg} / \mathrm{mL})$ were recorded against the Gramnegative bacterial strains ( $P$. aeruginosa, E. coli reference strain and UPEC clinical isolate, Acinetobacter 
baumannii) and C. parapsilosis. Our results showed that in case of the majority of the clinical strains, the $\mathrm{S}$ oxidized compound SH47 was more active compared to its precursor TH47, exhibiting MIC values two times lower than the corresponding non-oxidized compound. However, in the case of reference strains this trend was observed only in case of $P$. aeruginosa (Figures 2A, 2B and 3A, 3B).

For the fluorinated compounds (TH48, TH49, SH48, SH49) this trend was observed only in three cases for the TH49/SH49 couple, respectively against the $S$. aureus, $P$. aeruginosa and $E$. faecalis reference strains. The majority of microbial infections involve biofilm development on natural, intact or damaged tissues as

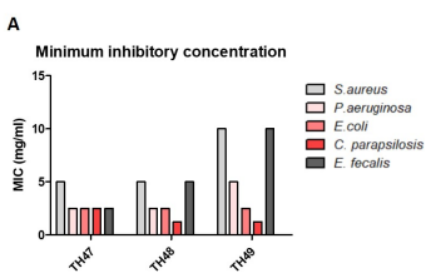

c

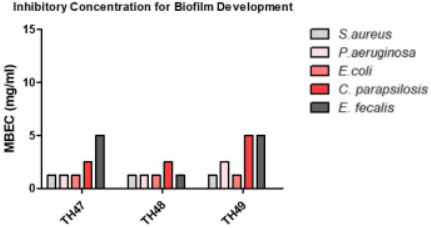

well as on artificial medical devices and are characterized by chronic evolution, middle intensity symptoms, and most importantly resistance to antimicrobial compounds. Many research efforts are done in order to provide novel agents acting as inhibitors of biofilm formation that act by disrupting the biofilm cells connection, rendering the microbial cells susceptible to usual therapeutic doses of antibiotics [3, 8, 10].

The experimental set up we employed within this study to test antibiofilm activity uses mini volumes and multiple well plastic plates, hence allowing the simultaneous testing of a large spectrum of concentrations.
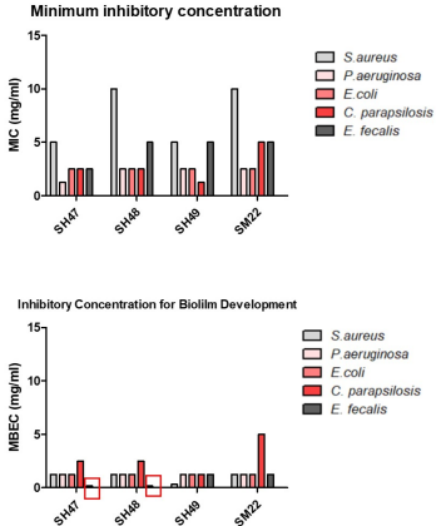

Figure 2.

Antimicrobial (A, B) and antibiofilm (C, D) activity of the novel dibenzothiepines against ATCC strains MIC - minimum inhibitory concentration; MBEC - minimal biofilm eradication concentration. The MIC was determined as the minimum amount of the tested compounds that inhibited the microbial growth in liquid medium after $24 \mathrm{~h}$ treatment. The minimal biofilm eradication concentration was determined to be the lowest concentration of the tested compounds at which the decrease in absorbance value, measured at $490 \mathrm{~nm}$, was observed in comparison to the positive control. Concentrations expressed as $\mathrm{mg} / \mathrm{mL}$ and are presented as the average of three different experiments.
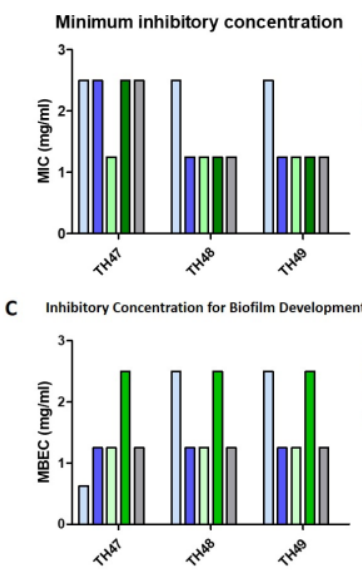
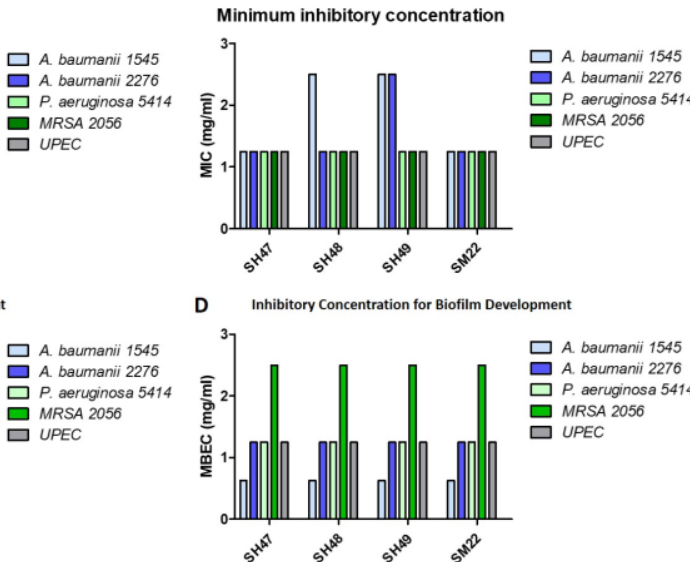

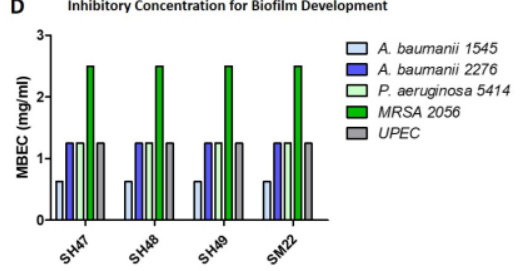

Figure 3.

Antimicrobial (A, B) and antibiofilm (C, D) activity of the novel dibenzothiepines against clinical isolates MIC - minimum inhibitory concentration; MBEC - minimal biofilm eradication concentration. The MIC was determined as the minimum amount of the tested compounds that inhibited the microbial growth in liquid medium $24 \mathrm{~h}$ after the treatment. The minimal biofilm eradication concentration was determined to be the lowest concentration of the tested compounds at which the decrease in absorbance value, measured at $490 \mathrm{~nm}$, was observed in comparison to the positive control.

Concentrations expressed as $\mathrm{mg} / \mathrm{mL}$ and are presented as the average of three different experiments. 
It is worth to mention that, despite the well-known high bofilm resistance to different antimicrobial agents, in our case, the analysis revealed that the effect on biofilm development on inert substrata was generally higher that recorded on the planktonic cells, for the majority of the tested compounds, the MBEC values being in some cases up to 16 times lower than the corresponding MIC values (Figures 2C, 2D and 3C, 3D). Importantly, the oxidized compounds SH47/ SH48/SH49 harboured a more intensive antibiofilm activity than their precursors (TH47, TH48, TH49) against one (the reference E. faecalis strain)/ two (the reference $E$. faecalis and the A. baumanii clinical strain 1545) / five (the A. baumannii clinical strain 1545 and all reference strains, except E. coli) strains.

Taken together, the obtained results revealed that the S-oxidized compound SH47 exhibited a much intensive antimicrobial activity against most of the tested planktonic microbial strains as compared to its precursor TH47, while the S-oxidized compounds SH48 and SH49 exhibited an improved antibiofilm effect compared to their precursors.

SH47 and SH48 exhibited the best anti - E. faecalis biofilm activity (with a MBEC of $0.156 \mathrm{mg} / \mathrm{mL}$ ), while SH49 the best anti - $S$. aureus biofilm activity (with an MBEC of $0.31 \mathrm{mg} / \mathrm{mL}$ ), proving their potential for the further development of antibiofilm agents against Gram-positive infections.

\section{Conclusions}

A series of novel dibenzothiepines were synthesized characterized using spectral and elemental analysis and screened for their microbicidal and antibiofilm properties against standard microbial strains and clinical isolates. The new compounds exhibited a broad spectrum of antimicrobial activity, improved for the S-oxidized compounds (SH). Some of the compounds inhibited the ability of these strains to form biofilms on the inert substratum. Further molecular modelling has to be undertaken in order to improve antimicrobial and antibiofilm effect.

\section{Conflict of interest}

The authors declare no conflict of interest.

\section{References}

1. Bădiceanu CD, Nuță DC, Missir AlV, Hrubaru M, Delcaru C, Dițu LM, Chifiriuc CM, Limban C, New derivatives of 2-thiophene carboxylic acid: synthesis, structure and antimicrobial studies. Farmacia, 2018; 66(2): 237-242.

2. Boruga O, Stanca HT, Bagiu IC, Horhat ID, Craciunescu M, Cosnita A, Berceanu Vaduva D, Chercota V, Milcu AI, Iovan C, Incidence of resistance phenotypes of Escherichia coli strains isolated from an obstretics and gynecology unit. Unicentric prospective transversal study. Rev Chim (Bucharest), 2018; 69(4): 1023-1025.
3. Costescu A, Ciobanu CS, Iconaru SL, Ghita RV, Chifiriuc CM, Marutescu LG, Predoi D, Fabrication, characterization, and antimicrobial activity, evaluation of low silver concentrations in silver-doped hydroxyapatite nanoparticles. J Nanomater., 2013; 2013: Art. 194854: $1-9$.

4. Drăgan M, Dragostin O, Iacob A, Profire L, Stan CD, Tuchiluș C, Antioxidant and antimicrobial potential of new azetidin-2-one of ferulic acid. Farmacia, 2019; 67(5): 789-793.

5. Dubaele S, Jahnke W, Schoepfer J, Fuchs J, Chene P, Inhibition of DNA helicases with DNA-competitive inhibitors. Bioorg Med Chem Lett., 2006; 16(4): 923-927.

6. Hengge R, Targeting bacterial biofilms by the Green Tea Polyphenol EGCG. Molecules, 2019; 24(13): 2403: 1-18.

7. Ilie C, Stecoza CE, Căproiu MT, Hău R, Guţă R, Nănău-Andreescu D, Synthesis and characterization of new dibenzo[b,e]thiepine derivatives. II. Rev Chim (Bucharest), 2009; 60(6): 588-591.

8. Jankovic A, Erakovic S, Ristoscu C, Mihailescu (Serban) N, Duta L, Visan A, Stan GE, Popa AC, Husanu MA, Luculescu CR, Srdic VV, Janackovic D, Miskovic-Stenkovic V, Bleotu C, Chifiriuc MC, Mihailescu IN, Structural and biological evaluation of lignin addition to simple and silver-doped hydroxyapatite thin films synthesized by matrixassisted pulsed laser evaporation. J Mat Sci Mat Med., 2015; 26(1): 1-14.

9. Janzen WP, Screening technologies for small molecule discovery: the state of the art. Chem Biol., 2014; 21(9): 1162-1170.

10. Lazar V, Quorum sensing in biofilms - How to destroy the bacterial citadels or their cohesion/power? Anaerobe, 2011; 17(6): 280-285.

11. Limban C, Chifiriuc MC, Antibacterial activity of new dibenzoxepinone oximes with fluorine and trifluoromethyl group substituents. Int J Mol Sci., 2011; 12(10): 6432-6444.

12. Nisa S, Blokpoel MCJ, Robertson BD, Tyndal, JDA, Lun S, Bishai WR, O'Toole R, Targeting the chromosome partitioning protein ParA in tuberculosis drug discovery. J Antimicrob Chemother., 2010; 65(11): 2347-2358.

13. Nuţă DC, Chifiriuc MC, Missir A, Chiriţă IC, Bădiceanu $\mathrm{CD}$, In vitro evaluation of the antibacterial and antifungal activity of some new N-(2-dialkylaminoethyl) benzanilides. Farmacia, 2010; 58(1): 38-45.

14. Perez-Pineiro R, Burgos A, Jones DC, Andrew LC, Rodriguez H, Suarez M, Fairlamb AH, Wishart DS, Development of a novel virtual screening cascade protocol to identify potential trypanothione reductase inhibitors. J Med Chem., 2009; 52(6): 1670-1680.

15. Siles SA, Srinivasan A, Pierce CG, Lopez-Ribot JL, Ramasubramanian AK, High-Throughput screening of a collection of known pharmacologically active small compounds for identification of Candida albicans biofilm inhibitors. Antimicrob Agents Chemother., 2013; 57(8): 3681-3687.

16. Stecoza CE, Ilie C, Drăghici C, Căproiu MT, New 2-methyl-O-acyloximino-dibenzo[b,e]thiepins. Synthesis and structural characterization. Rev Chim (Bucharest), 2011; 62(6): 610-613. 
FARMACIA, 2020, Vol. 68, 6

17. Stecoza CE, Majekova M, Majek P, Căproiu TM, Măruțescu L, Novel dibenzothiepins with antibiofilm activity demonstrated by microbiological assays and molecular modelling. Curr Org Chem., 2013; 17(2): 113-124.

18. Szymański P, Markowicz M, Mikiciuk-Olasik E, Adaptation of High-Throughput Screening in drug discovery-Toxicological screening tests. Int $\mathrm{J} \mathrm{Mol}$ Sci., 2012; 13(1): 427-452.

19. Thangamani S, Mohammad H, Younis W, Seleem MN, Drug repurposing for the treatment of staphylococcal infections. Curr Pharm Des., 2015; 21(16): 2089-2100.
20. Zarafu I, Turcu I, Culiță DC, Petrescu S, Popa M, Chifiriuc MC, Limban C, Telehoiu A, Ioniţă P, Antimicrobial features of organic functionalized graphene-oxide with selected amines. Materials, 2018; 11(9): 1704: 1-10.

21. Zheng W, Sun W, Simeonov A, Drug repurposing screens and synergistic drug-combinations for infectious diseases. Br J Pharmacol., 2018; 175(2): 181-191. 